\title{
VECTORS AND KEY FACTORS OF THE DYNAMICS OF LANGUAGES IN THE SECONDARY EDUCATION SYSTEM IN THE REPUBLIC OF AZERBAIJAN IN 1990-2020
}

\author{
Moskvitcheva Svetlana ${ }^{1}$, Abdullaev Ramil ${ }^{2}$ \\ ${ }^{1}$ Associate professor, Ph.D., Peoples' Friendship University of Russia (RUDN University), Russian \\ Federation, moskvitcheva@mail.ru \\ ${ }^{2}$ Postgraduate student, Peoples' Friendship University of Russia (RUDN University), Russian \\ Federation, abdullayevram@gmail.com
}

\begin{abstract}
This article analyses the dynamics of the language policy of the Republic of Azerbaijan in the field of general secondary education from the moment when the country gained independence down to our days. It also considers the questions of strategies in the choice of languages of teaching and languages learned as a discipline. The study shows that this choice is due to a number of factors of geopolitical, economic, social, cultural and religious origin. It also demonstrates the growth of the role and influence of the Azerbaijani language and its transformation into the dominant language in the field of school education. Three periods are distinguished in the dynamics of the functions of the Azerbaijani language: the first period refers to the first years of independence and is characterized to a greater extent by symbolic decisions in the spirit of national romanticism. The second period (the turn of the 20th and 21st centuries), pragmatic, was aimed at strengthening the state independence of the Republic and its unity. We focus here on the issues of language policy. The third period began in the 2010s and is characterized by enhanced measures aimed at both corpus and status planning. Here, the main efforts were focused on language planning. The paper investigates the status and functions of the Russian language, the former "language of interethnic communication" of the peoples of the USSR, which, in fact, was the state language on the territory of the USSR. In this paper, we discuss the place of the languages of national (ethnic minorities) in the education system of the Republic of Azerbaijan.
\end{abstract}

Keywords: Azerbaijan, languages in the education system, the Azerbaijani language, the Russian language, languages of national minorities, educational strategies, language policy, educational policy.

\section{INTRODUCTION}

The independent states that were formed in the early 90s on the territories of the former Union republics of the USSR faced the need to search for new principles of organization and the choice of priorities in both domestic and foreign policy. This equally applied to the geopolitical orientations of the newly formed countries, vectors of economic, political and cultural partnership, the nature of measures aimed at strengthening the territorial and national (civil) unity of the state, and also developing strategies to defend 
independence in the face of possible external threats. In the hierarchy of these problems, issues related to the field of language and educational policy closely connected with it turned out to be far from secondary. On the contrary, for all post-Soviet states, without any exception, the language issue became the primary and one of the central issues of domestic policy. It, in fact, included at least three aspects: the issue of the status of the titular language of the republic, the issue of the status, place and functions of the Russian language, the issue of politics in relation to languages of ethnic (national) minorities.

In the field of education, in particular at the level of the secondary school (which is of interest to us), all the republics faced the question of the leading language of instruction ${ }^{1}$. It is worth emphasizing that during the Soviet period, the position of the titular languages ${ }^{2}$ in the republics was stable: there were schools with a full cycle of instruction in these languages, a number of languages were widely present in the higher education system, and a significant amount of literature in these languages was published. It can be argued that such sociolinguistic categories as 'native language' and 'national language' were extremely significant in the ideological and propaganda space of the USSR (Moskvitcheva 2019). However, within a single state with a strong vertical of power, there was a strong competition of the titular regional languages with the Russian language, which did not have the status of the state language, but de facto, it was. In most of the republics, there were even more acute issues of competition between the so-called 'national schools' (where instruction was conducted in the titular language), and 'Russian schools' (with teaching in Russian), the level of which was often higher for objective and subjective reasons. Besides, the dissolution of the USSR caused and escalated in the former republics the problem of the relationship between the state language (the former titular language of the republic) and the languages of national minorities that demanded large linguistic rights for their native languages and chose schools with the Russian language of instruction. The whole range of these problems was fully characteristic of the independent Republic of Azerbaijan.

\section{PROBLEMATICS AND RESEARCH QUESTIONS}

This article proposes to consider the status, place and functions of the Azerbaijani language, the Russian language, languages of ethnic minorities of Azerbaijan, and also languages that are officially included in the category "foreign language" in the secondary school system of the Republic of Azerbaijan (hereinafter RA). The authors examine the role and the status of languages with respect to the broad context of internal political tasks, as well as geopolitical, economic and cultural ties and strategic priorities of Azerbaijan, without which the analysis of the language policy in the field of education is impossible. The paper proposes to sequentially investigate the following issues:

- General strategy of the language policy in Azerbaijan;

- Main challenges of language policy and planning in education;

- Goals and objectives of the government Vs needs of society;

- Languages in the system of school education in the Republic of Azerbaijan;

- Types of curricula depending on the language of teaching and the language of learning.

\section{PROBLEM INVESTIGATION}

\subsection{General Strategy of the Language Policy in Azerbaijan}

The uncertainty and fluctuations of both domestic and foreign policy after the dissolution of the Soviet Union, naturally, led to policy fluctuations towards the place and role of languages in the education system. As a result, since the mid-90s (but in fact since 1993, with the coming to power of President Heydar Aliyev), the government of the Republic of Azerbaijan has chosen and strictly adheres to a strategy where the two main priorities are strengthening unity and independence of the country. Table 1 shows the main legislative acts of the Republic of Azerbaijan related to language policy.

Table 1. Main legislative acts regulating the use of the language in public space

\begin{tabular}{|c|c|c|c|}
\hline № & Date & Document's name & Type of document \\
1. & 02.02 .1991 & $\begin{array}{c}\text { On the preparation of the draft of the new } \\
\text { Azerbaijani alphabet (Decision of the S.S. 1991a) }\end{array}$ & $\begin{array}{c}\text { Decision of the Supreme Soviet } \\
\text { of the Azerbaijan SSR N 1980- } \\
\text { XI }\end{array}$ \\
\hline
\end{tabular}

\footnotetext{
${ }^{1}$ This also applied to the Russian Federation, but there the problem was different and mainly affected the relationship between the Russian-speaking center and the position of titular languages in the Republics of the Russian Federation.

2 The title language is understood as the language that coincides with the name of the Republic.
} 
IJAEDU- International E-Journal of Advances in Education, Vol. VI, Issue 18, December, 2020

\begin{tabular}{|c|c|c|c|}
\hline 2. & 09.02 .1991 & $\begin{array}{l}\text { Development of the new Azerbaijani alphabet } \\
\text { (Decision of the S.S. 1991b) }\end{array}$ & $\begin{array}{l}\text { Decision of the Supreme Soviet } \\
\text { of the Republic of Azerbaijan N } \\
\qquad 70-\text { XII }\end{array}$ \\
\hline 3. & 25.12.1991 & $\begin{array}{l}\text { Law "On restoration of the Azerbaijani alphabet } \\
\text { based on Latin script" (Law 1991) }\end{array}$ & $\begin{array}{c}\text { President of The Republic Of } \\
\text { Azerbaijan } \\
\text { Law N } 33\end{array}$ \\
\hline 4. & 25.12.1991 & $\begin{array}{l}\text { On the procedure for entry into force of the Law of } \\
\text { the Republic of Azerbaijan "On restoration of the } \\
\text { Azerbaijani alphabet based on Latin script" } \\
\text { (Decision S.S.1991c) }\end{array}$ & $\begin{array}{l}\text { Decision of the Supreme Soviet } \\
\text { of the Republic of Azerbaijan N } \\
\qquad 34\end{array}$ \\
\hline 5. & 22.12.1992 & $\begin{array}{c}\text { Law of the Azerbaijan Republic "About the state } \\
\text { language of the Republic of Azerbaijan" (Law } \\
\text { 1992) } \\
\text { (Out of force) }\end{array}$ & $\begin{array}{l}\text { President of the Republic of } \\
\text { Azerbaijan } \\
\text { Law N } 413\end{array}$ \\
\hline 6. & 22.12.1992 & $\begin{array}{c}\text { On the entry into force of the law "About the state } \\
\text { language of the Republic of Azerbaijan" (Decision } \\
\text { of the Milli Majlis 1992) } \\
\text { (Out of force) }\end{array}$ & $\begin{array}{l}\text { Decision of the Milli Majlis } \\
\text { (parliament) of the Republic of } \\
\text { Azerbaijan } \\
\text { N } 414\end{array}$ \\
\hline 7. & 1995 & $\begin{array}{l}\text { Constitution of the Republic of Azerbaijan, part 1, } \\
\text { article } 21 \text { (Constitution 1995) }\end{array}$ & Nationwide referendum \\
\hline 8. & 18.06 .2001 & $\begin{array}{l}\text { About Improving the use of the state language } \\
\text { (Decree 2001) }\end{array}$ & $\begin{array}{l}\text { Decree of the President of the } \\
\text { Republic of Azerbaijan N } 506\end{array}$ \\
\hline 9. & 30.09 .2002 & $\begin{array}{l}\text { Law of the Republic of Azerbaijan "About the state } \\
\text { language of the Republic of Azerbaijan» (Law } \\
\text { 2002) }\end{array}$ & $\begin{array}{l}\text { President of the Republic of } \\
\text { Azerbaijan } \\
\text { Law N 365-IIQ }\end{array}$ \\
\hline 10. & 23.05 .2012 & $\begin{array}{l}\text { State program on the use of the Azerbaijani } \\
\text { language in the context of globalization in } \\
\text { accordance with the requirements of the time and } \\
\text { the development of linguistics in the country } \\
\text { (Order 2012) }\end{array}$ & $\begin{array}{l}\text { Order of the President of the } \\
\text { Republic of Azerbaijan }\end{array}$ \\
\hline 11. & 17.07.2018 & $\begin{array}{l}\text { On a number of measures to ensure wider use of } \\
\text { the Azerbaijani language online (Order 2018) }\end{array}$ & $\begin{array}{l}\text { Order of the President of the } \\
\text { Republic of Azerbaijan }\end{array}$ \\
\hline 12. & 01.11 .2018 & $\begin{array}{c}\text { On measures to protect the purity of the } \\
\text { Azerbaijani language and further improve the use } \\
\text { of the state language (Decree 2018) }\end{array}$ & $\begin{array}{l}\text { Decree of the President of the } \\
\text { Republic of Azerbaijan }\end{array}$ \\
\hline
\end{tabular}

Based on the analysis of this table, we can draw a number of conclusions. First, there are three peaks of legislative activity in RA. The first of them (1991-1993) is associated with the period of national romanticism and the ideas of Pan-Turkism in the ideology and politics of Azerbaijan. During this period, a number of laws were adopted, which were mainly of a symbolic nature. In accordance with the spirit of the times and ideology, the Azerbaijani language received the name Turkic, which could not but cause discontent and protests from the ethnic and national minorities of Azerbaijan, who saw this as a threat to their position. Heydar Aliyev, who became the third President of Azerbaijan on October 10, 1993, changed the internal political course of the Republic in the field of language policy to pragmatic attitudes, first of all, to the priority of strengthening the unity and independence of the country, in which language played an important role. The laws of the second stage (the late 90 s - early 2000s) reflect this language policy. The language began to be called Azerbaijani. The third stage is associated with the name of the fourth president llham Aliyev and characterizes the transition from ideological attitudes to proper language planning in the vector of normalization and introduction of the Azerbaijani language into all fields of activity. In this sense, the 
legislative acts of 2012 and 2018 are especially important. As a result, by 2020, the Azerbaijani language had firmly taken the place of the undoubtedly leading language in public administration in general and in the school education system in particular. According to the Ministry of Education of the Republic of Azerbaijan in 2020 , out of 4,472 schools, 4,131 teach in the state (Azerbaijani) language, which is the language of instruction for $93 \%$ of schoolchildren. At the same time, the Russian language was not completely ousted from the education system, as it happened in most post-Soviet states.

\subsection{Main Challenges of Language Policy and Planning in Education}

Firstly, these are challenges associated with the Azerbaijani language itself, with the level of its normativization (standardization and codification) and normalization (the level and structural parameters of functioning in society). Despite the high status of the Azerbaijani language in the Soviet period (as a matter of fact, it was one of the few languages that received the state status according to the 1978 Constitution even the Russian language de facto did not have the state status), Azerbaijani remained a regional language and could not compete with Russian in the most prestigious areas, including education, which determined its structural and functional features. Secondly, we should pay attention to the continuing competition with the Russian language after independence, status and prestige of which, the needs for which and the loyalty to which from the elites remain high. At the same time, knowledge of the Azerbaijani language and its use in the Republic at the level of everyday communication has always been and remained extremely high, which in fact guaranteed the success of the language policy in the vector of normalization. Thus, according to the results of the 2009 census of population, 99.7 percent of Azerbaijanis recognized the Azerbaijani language as their native language, and 99.9 percent declared their fluency. In all, 98.6 percent of the population of Azerbaijan is fluent in Azerbaijani. Thirdly, there is a need for a balanced policy in relation to national minorities and their languages, primarily, to the largest of them, Lezgins and Talysh. When panning national and language policy, of the three possible configurations, which include assimilation, segregation and language support in the vector of ensuring maximum social and territorial mobility, the latter was chosen. Fourthly, it is taking into account (including in the field of education) the interests of large regional players (which primarily include Russia, Turkey, Iran and the USA) in the geopolitical space of the South Caucasus. Finally, fifthly, it is necessary to take into account the role of historical civilizational, cultural and religious factors in the region. In this aspect, if we are talking about languages, the following come to the fore: Arabic - as the language of the Koran and Islam in general, Farsi - as the language of the high medieval culture of Azerbaijan and Russian - as the language of high urban culture since the second half of the 19th century and the language of Soviet culture of the 20th century.

\subsection{Goals and Objectives of the Government Vs Needs of Society}

Slightly simplifying, the needs of society can be reduced to two main types: the desire for a decent standard of living (income) and the associated pragmatic needs including social and geopolitical mobility, and also needs for identity which implies comfortable conditions that do not contradict the value structure of identity. These types of needs are associated with expectations from the education system as a whole and from its linguistic component on the part of society. The main goal of the government, as mentioned above, is, first of all, the internal stability of the country and the course towards strengthening independence.

Thus, the education system should contribute to the formation of a civic nation and the loyalty of its members to the state, to respond both to the pragmatic demands of the population as a whole and to the demands of individual social and national groups striving, among other things, to preserve their linguistic and cultural identity. Language proficiency also determines the vectors of both social and territorial mobility. All this set of factors makes the offer/choice of both the language of teaching and the choice of languages of learning at schools crucial. The course towards strengthening independence and forming a civil nation has also found expression in the gradual increase in the role of the Azerbaijani language, which by now has taken absolutely dominant positions as a language of teaching. Since the need for the Russian language remains high, first of all, from an economic perspective, it retained a significant and specific place in education. Among foreign languages, the undisputed leadership, for obvious reasons, belongs to English. Arabic and Farsi have a strong place in the cultural and religious sphere of life and are also taught in secondary school.

\subsection{Languages in the System of School Education in the Republic of Azerbaijan}

The sociolinguistic categorization of languages within the school education system includes three nominations defined by law: the state language (Azerbaijani) ${ }^{7}$, languages of national minorities, and a foreign language.

3.4.1. Azerbaijani is the main language of instruction in the vast majority of educational institutions. In total, about $93 \%$ of secondary school students are taught in Azerbaijani. The Azerbaijani language is also a 
compulsory subject in all non-Azerbaijani language schools. In schools' curricula, it is called «Azerbaijani as the state language».

3.4.2. A foreign language is chosen from among the following languages: English, Arabic, German, Russian, Farsi and French. Teaching a foreign language starts from the first grade in all secondary schools, the choice of language is determined by the wishes of the parents. Since 2015, the school curriculum provides for the compulsory study of two foreign languages; before that, the second foreign language was an optional subject. Schoolchildren begin to study the second foreign language in the 5th grade.

In a media interview, the representative of the Ministry of Education Ohliyyət Adıgözəlov noted: "According to rough estimates, 90-95 percent of English is taught in our schools as the first foreign language. In schools where the main foreign language is English, we observe that the second foreign language is Russian. Naturally, there are also schools with French and German as a second foreign language. In addition, we have schools with the main foreign languages - French, German; however, the number of these schools is very small. Schools, where Arabic is taught, are very scarce" (Ikinci xarici dil öyrənirsənmi?, 2018).

In order to find out the preferences of the students, journalists interviewed 73 students of a school in Baku that teaches in the Azerbaijani language. Each student was asked to indicate two languages that he or she would like to learn. The results of the interview were as follows: 43 students expressed a desire to learn English, 46 - Russian, 22 - French, 17 - Arabic, 16 - German and 2 - Persian (İkinci xarici dil öyrənirsənmi?, 2018).

3.4.3. The Russian language occupies a special place in the structure of education. Legally, it has the only status of a 'foreign language in the education system'. However, its functions are much broader. In September 2020, there are 15 full-cycle schools in the Republic of Azerbaijan with teaching entirely in Russian. The geography of these schools is as follows: 1 school in the city of Nakhchivan, 3 - in Balakan, 3 - in Gabala, 2 - in Guba, 2 - in Gusar, 1 - in Gakh, 1 - in Zagatala, 1 - in the Goranboy region and 1 - in Khachmaz region. The total number of students in these schools is 3,582. There are also Russian sectors along with Azerbaijani in 314 schools. In the Russian sector, teaching is performed entirely in Russian. The total number of schoolchildren studying in the Russian branches of these schools is 82,535 . Until 1998 , the Russian language was compulsory in all schools in Azerbaijan. In 1998, it entered the 'Foreign Language' category, remaining mandatory, and since 2002, it has become optional (Wikipedia, Russkij yazyk v Azerbajdzhane). At the same time, the interest in and demand for the Russian language in the Republic remains high. Since 2010, 50 schools with the compulsory study of Russian as a foreign language have been reopened in the country. In 2020, the total number of schoolchildren studying Russian in one form or another was 450,000, which is $32 \%$ of the 1,416,000 schoolchildren in Azerbaijan (Təhsil eksperti, 2018).

Thus, the Russian language functions in the schools of the RA as the language of instruction, first foreign language and second foreign language.

3.4.4. English is mainly taught as the main (first) and second foreign language. However, since 1998, the socalled Oxford School has been operating in Baku. Its term of apprenticeship is 12 years, training is conducted entirely in English. The school has 550 students, 30\% of them are children of foreigners. In November 2010, Shamkir branch of Baku Oxford School was opened. Currently, 220 students study here (Prezident Bakı Oksford məktəbində, 2014).

3.4.5. The Georgian language also occupies a special place: in one of the schools of the Republic (Alibejli, Gah region), there is a sector with instruction in the Georgian language, which brings Georgian closer to Russian. However, the Georgian language does not have the status of a foreign language and as such is not taught in any of the republic's schools.

3.4.6. The languages of national minorities present to one degree or another in the education system are: Avar, Lezgian, Kurdish, Talysh, Tat, Udi, Khinalug and Tsakhur. A special place is occupied by the Lezgian language, which is taught as a school subject in 108 schools of the Republic. Lessons are performed from 1 to 9 grades 1 hour a week. The rest of the above minority languages appear in the curriculum from grades 1 to 4, 1 hour a week. The Talysh language, the fourth largest minority in Azerbaijan, is taught in 225 schools (Azərbaycanda ləzgi dilində 108, talış dilində 225 məktəb var, 2018). For the languages of the Iranian group, Farsi can serve as partial compensation for it can be chosen as a foreign language.

\section{TYPES OF CURRICULA DEPENDING ON THE LANGUAGE OF TEACHING AND THE LANGUAGE OF LEARNING}

The existing types of curricula for grades 1-11 are presented in the Table 'Types of curricula in a complete secondary school, depending on the language factor'. 
IJAEDU- International E-Journal of Advances in Education, Vol. VI, Issue 18, December, 2020

Table 2. Types of curricula in a complete secondary school, depending on the language factor 20202021

Curriculum 1: For comprehensive schools (teaching in Azerbaijani)

\begin{tabular}{|c|c|c|c|c|c|c|c|c|c|c|c|c|}
\hline \multirow[b]{2}{*}{$\mathrm{N}$} & \multirow[t]{2}{*}{ Subject } & \multicolumn{11}{|c|}{ Number of lessons per week by class } \\
\hline & & $\mathrm{T}$ & II & III & IV & $\mathrm{V}$ & $\overline{\mathrm{VI}}$ & $\overline{\mathrm{VII}}$ & $\overline{\mathrm{VIII}}$ & IX & $\bar{X}$ & $\overline{\mathrm{XI}}$ \\
\hline 1 & The Azerbaijani language & 9 & 10 & 10 & 10 & 5 & 4 & 4 & 3 & 2 & 3 & 3 \\
\hline 2 & First foreign language & 1 & 1 & 1 & 1 & 3 & 3 & 3 & 3 & 2 & 4 & 4 \\
\hline 3 & Second foreign language & & & & & 1 & 1 & 1 & 1 & 1 & 2 & 2 \\
\hline
\end{tabular}

Curriculum 2: For comprehensive schools (teaching in Russian)

\begin{tabular}{|c|c|c|c|c|c|c|c|c|c|c|c|c|}
\hline & & \multicolumn{11}{|c|}{ Number of lessons per week by class } \\
\hline $\mathrm{N}$ & Subject & $\mathrm{I}$ & II & III & IV & $\mathrm{V}$ & VI & VII & VIII & IX & $\mathrm{X}$ & $\mathrm{XI}$ \\
\hline 1 & The Russian language & 9 & 10 & 10 & 10 & 5 & 4 & 4 & 3 & 2 & 3 & 3 \\
\hline 2 & $\begin{array}{l}\text { Azerbaijani as the state } \\
\text { language }\end{array}$ & 2 & 2 & 2 & 2 & 2 & 2 & 2 & 2 & 2 & 2 & 2 \\
\hline$\overline{3}$ & First foreign language & 1 & 1 & 1 & 1 & 3 & 3 & 3 & 3 & 2 & 4 & 4 \\
\hline 4 & Second foreign language & & & & & 1 & 1 & 1 & 1 & 1 & 2 & 2 \\
\hline
\end{tabular}

Curriculum 3: For comprehensive schools (teaching in Georgian)

\begin{tabular}{|c|c|c|c|c|c|c|c|c|c|c|c|c|}
\hline \multirow[b]{2}{*}{$\mathrm{N}$} & \multirow[t]{2}{*}{ Subject } & \multicolumn{11}{|c|}{ Number of lessons per week by class } \\
\hline & & $\mathrm{I}$ & II & III & IV & $\mathrm{V}$ & $\mathrm{VI}$ & VII & VIII & $\mathrm{IX}$ & $\bar{X}$ & $\overline{X I}$ \\
\hline 1 & The Georgian language & 9 & 10 & 10 & 10 & 5 & 4 & 4 & 3 & 2 & 3 & 3 \\
\hline 2 & $\begin{array}{c}\text { Azerbaijani as the state } \\
\text { lanquaqe }\end{array}$ & 2 & 2 & 2 & 2 & 2 & 2 & 2 & 2 & 2 & 2 & 2 \\
\hline 3 & First foreign language & 1 & 1 & 1 & 1 & 3 & 3 & 3 & 3 & 2 & 4 & 4 \\
\hline 4 & Second foreign language & & & & & 1 & 1 & 1 & 1 & 1 & 2 & 2 \\
\hline
\end{tabular}

\section{Curriculum 4: Lezgian comprehensive schools (teaching in Azerbaijani)}

\begin{tabular}{|c|c|c|c|c|c|c|c|c|c|c|c|c|}
\hline \multirow[b]{2}{*}{$N$} & \multirow[b]{2}{*}{ Subject } & \multicolumn{11}{|c|}{ Number of lessons per week by class } \\
\hline & & 1 & II & IIII & IV & $\mathrm{V}$ & $\mathrm{VI}$ & VII & VIII & IX & $\bar{X}$ & $\mathrm{XI}$ \\
\hline 1 & The Azerbaijani language & 8 & 9 & 9 & 9 & 5 & 4 & 4 & 3 & 2 & 3 & 3 \\
\hline 2 & The Lezgian language & 1 & 1 & 1 & 1 & 1 & 1 & 1 & 1 & 1 & & \\
\hline 3 & First foreign language & 1 & 1 & 1 & 1 & 2 & 2 & 2 & 2 & 1 & 4 & 4 \\
\hline 4 & Second foreign language & & & & & 1 & 1 & 1 & 1 & 1 & 2 & 2 \\
\hline
\end{tabular}

Curriculum 5: Lezgian for comprehensive schools (teaching in Russian)

\begin{tabular}{|c|c|c|c|c|c|c|c|c|c|c|c|c|}
\hline \multirow[b]{2}{*}{$\mathrm{N}$} & \multirow[b]{2}{*}{ Subject } & \multicolumn{11}{|c|}{ Number of lessons per week by class } \\
\hline & & $\mathrm{T}$ & II & IIII & IV & $\mathrm{V}$ & $\mathrm{VI}$ & VII & VIII & IX & $\bar{X}$ & $\overline{\mathrm{XI}}$ \\
\hline 1 & The Russian language & 8 & 9 & 9 & 9 & 5 & 4 & 4 & 3 & 2 & 3 & 3 \\
\hline 2 & $\begin{array}{l}\text { Azerbaijani as the state } \\
\text { language }\end{array}$ & 2 & 2 & 2 & 2 & 2 & 2 & 2 & 2 & 2 & 2 & 2 \\
\hline 3 & The Lezgian language & 1 & 1 & 1 & 1 & 1 & 1 & 1 & 1 & 1 & & \\
\hline 4 & First foreign language & 1 & 1 & 1 & 1 & 2 & 2 & 2 & 2 & 1 & 4 & 4 \\
\hline 5 & Second foreign language & & & & & 1 & 1 & 1 & 1 & 1 & 2 & 2 \\
\hline
\end{tabular}




\section{CONCLUSION}

The Analysis of the language policy in the field of general secondary education in the Republic of Azerbaijan allows us to draw the following conclusions. First, the choice and status of languages, as well as their sociolinguistic categorization, depend on a variety of cultural, economic, political and geopolitical parameters. The volume of this article does not allow presenting a detailed analysis of the choice of languages depending on the above factors, but general trends have been identified. Secondly, to date, the Azerbaijani language, thanks to efforts and a well-thought-out policy, occupies an absolutely leading position in the field of secondary education. It is either the language of instruction or is compulsorily studied in all schools with a language of instruction other than Azerbaijani as the state language. Thirdly, interest in the Russian language in the Republic remains high, and its place in the education system is unique since it can act as a language of instruction, but also successfully acts as a first (main) or second foreign language. It quite successfully competes with the English language in this role. Fourthly, the languages of national minorities are present in the secondary education system. They are taught according to the classical model, common in many world systems. The purpose of teaching is to maintain the language with a general strategy for the further transition to either Azerbaijani or Russian languages of instruction. In general, we can say that this type of language policy in the field of education meets the strategic and tactical tasks of the RA.

\section{ACKNOWLEDGEMENT}

The publication has been prepared with the support of the "RUDN University Program 5-100" and was financially supported by the research program of the Institute of Modern Languages, Intercultural Communication and Migrations at the Faculty of Philology "Functional distribution and typology of the need for languages among migrants in an urbanized environment" (research project № 056112-0-000).

\section{REFERENCE LIST}

Azərbaycanda ləzgi dilində 108, talış dilində 225 məktəb var. In: toplum.tv. https://toplum.tv/az/azerbaycanda-lezgi-dilinde-108-talis-dilinde-225-mekteb-var/\#.X15uAxAzbIV [date of accessed: 10.09.2020]

Constitution 1995. (1995). Constitution of the Republic of Azerbaijan, part 1, article 21. http://eqanun.az/framework/897 [date of accessed: 12.09.2020]

Decision of the S.S. 1991a. (1991). Decision of the Supreme Soviet of the Azerbaijan SSR N 1980-XI "On the preparation of the draft of the new Azerbaijani alphabet". http://e-qanun.az/framework/6483 [date of accessed: 12.09.2020]

Decision of the S.S. 1991b. (1991). Decision of the Supreme Council of the Republic of Azerbaijan N 70-XII, "On the Development of the new Azerbaijani alphabet". http://e-qanun.az/framework/10280 [date of accessed: 12.09.2020]

Decision of the S.S.1991c. (1991). President of The Republic of Azerbaijan Law N 33, "On restoration of the Azerbaijani alphabet based on Latin script". http://e-qanun.az/framework/6803 [date of accessed: 12.09.2020]

Decision of the Milli Majlis 1992. (1992). Decision of the Milli Majlis of the Republic of Azerbaijan N 414 "On the entry into force of the law "About the state language of the Republic of Azerbaijan"”. http://eganun.az/framework/7962 [date of accessed: 12.09.2020]

Decree 2001. (2001). Decree of the President of the Republic of Azerbaijan N 506, 2001 "About Improving the use of the state language". http://e-qanun.az/framework/3568 [date of accessed: 12.09.2020]

Decree 2018. (2018). Decree of the President of the Republic of Azerbaijan "On measures to protect the purity of the Azerbaijani language and further improve the use of the state language". http://eqanun.az/framework/40441 [date of accessed: 12.09.2020]

İkinci xarici dil öyrənirsənmi?. In: Azərbaycan müəllimi. https:/www.muallim.edu.az/news.php?id=2587 [date of accessed: 10.09 .2020$]$

Law of 1991. (1991). Law of the Republic of Azerbaijan N 33 "On restoration of the Azerbaijani alphabet based on Latin script. http://e-qanun.az/framework/6803 [date of accessed: 12.09.2020] 
Law of 1992. (1992). Law of the Republic of Azerbaijan N 413 "About the state language of the Republic of Azerbaijan". http://e-qanun.az/framework/7961 [date of accessed: 12.09.2020]

Law of 2002. (2002). Law of the Republic of Azerbaijan N 365-IIQ "About the state language of the Republic of Azerbaijan". http://e-qanun.az/framework/1865 [date of accessed: 12.09.2020]

Order 2012. (2012). Order of the President of the Republic of Azerbaijan "State program on the use of the Azerbaijani language in the context of globalization in accordance with the requirements of the time and the development of linguistics in the country". http://e-qanun.az/framework/23583 [date of accessed: 12.09.2020]

Order 2018. (2018). Order of the President of the Republic of Azerbaijan "On a number of measures to ensure wider use of the Azerbaijani language online". http://baku.edu.gov.az/az/pdf/9/3459 [date of accessed: 12.09 .2020$]$

Moskvitcheva, S. (2019). Prototypical Notions of Minority Languages in the Soviet Union and Russia: "Native Language" (rodnoj âzyk) and "National Language" (nacional'nij âzyk). In: Moskvitcheva, S. \& Viaut A. (eds.). Minority Languages from Western Europe and Russia. Comparative Approaches and Categorical Configurations. Cham: Springer (Serie Language Policy), pp. 49-69

Prezident Bakı Oksford məktəbində. In: azvision.az. https://azvision.az/news/46615/prezident-baki-oksfordmektebinde-fotolar.html [date of accessed: 08.09.2020]

Təhsil eksperti: Məktəblərdə rus bölməsi ləğv olunmalıdır. In: oxu.az. https://oxu.az/society/272277 [date of accessed: 10.09.2020]

Wikipedia. Russkij yazyk v Azerbajdzhane. https://ru.wikipedia.org/wiki/Русский язык в Азербайджане [date of accessed: 10.09.2020] 